\title{
Burnout among Primary and Secondary School Teachers in Samarahan District
}

\author{
Frankie Subon $^{1}$, Macdonald Methodius Sigie ${ }^{2}$ \\ ${ }^{\prime}$ (Mara University of Technology, Malaysia) \\ ${ }^{2}$ (Mara University of Technology, Malaysia)
}

\begin{abstract}
Burnout phenomenon in the teaching career is worth given a fair attention because if left unchecked, it can lead to detrimental effects on teachers, students and the teaching career itself. This study aims to discover the burnout level of primary and secondary school teachers in Samarahan District as measured by their scores on Emotional Exhaustion, Physical Exhaustion, Depersonalisation and Reduced Personal Accomplishment items. Besides, it also aims to find out whether significant relationships exist between teacher burnout dimensions and teachers' period of service, subject option and the school setting. Fifty teachers were randomly selected as sample and a Survey design using a questionnaire was employed as a data collection tool in this study. The questionnaire was adapted from Maslach Burnout Inventory (1982) focusing mainly on 4 categories of teacher burnout symptoms. Descriptive statistics and inferential statistics were employed for its data analysis. It was found that the teachers of the two schools had a moderate level of burnout. In contrast with past findings, it was also found that the teachers' subject option and the school setting did not have any significant relationship with teacher burnout. However, the teachers' period of service had a significant relationship with teacher burnout which ascertained the results of past studies. Recommendations were made for future research.
\end{abstract}

Keywords - burnout, depersonalisation, exhaustion, stress, symptoms

\section{Introduction}

Stress in teaching is not a new phenomenon in Malaysia. Apparently, teaching is among one of the most stressful professions because potentially high levels of stress can be generated on a regular basis in the teaching career as it is contributed by many factors within the school environment" (Juriani Jamaludin \& Ghaziah Mohd Ghazali, 2013). In one way or another, teachers are bound to be physically or mentally drained out after a long period of teaching service and undergoing a mundane routine year in and year out especially when they failed to adapt to new changes. Mayben (2008) contends that teaching can be considered a high-stress occupation because the education system exhibits all the elements associated with stress: a bureaucratic structure, continuous evaluation of its processes and outcomes, and increasingly intensive interpersonal interactions with students, parents, colleagues, principals and the community. In addition, Mayben also reasons that miscellaneous of other issues such as "increased student misconduct, student apathy, overcrowded classrooms, inadequate salaries, demanding or unsupportive parents, budgetary constraints, expanding administrative loads, lack of infrastructural support, and an increasingly negative public opinion have contributed to an embattled and embittered teacher force in America and throughout the world."

This phenomenon in the teaching career is worth given a fair attention because if left unchecked, all this can lead to teacher burnout. A few studies that have been conducted in Malaysia regarding teacher stress (Abd. Suseela Malakolunthu, 1994; Junaidah Abd. Jamil, 1996; Mohd Razali Othman \& Abg Mat Ali Abg Masagus, 1998; Mokhtar Ahmad, 1995; Mukundan \& Khandehroo, 2010; Juriani Jamaludin \& Ghaziah Mohd Ghazali, 2013) identified students' attitudes, workload, and having to teach poorly motivated students as stressors. Therefore, it is important to conduct this study to determine the burnout level of primary and secondary school teachers in Samarahan District as measured by their scores on Emotional Exhaustion, Physical Exhaustion, Depersonalisation and Personal Accomplishment items. Besides, this study also aims to find out whether significant relationships exist between teacher burnout dimensions and their period of service, subject option and the school setting.

\subsection{Background of the study}

Teaching is a challenging career to accomplish as it demands a lot of commitments and requires physical, emotional and mental strengths. In today's education scenario, teachers' workload seems unbearable. It is increasing year after year as they have to accomplish a multitude of responsibilities. Besides fulfilling their core responsibilities in the classroom, they also need to accomplish other non-teaching chores such as doing records and reports about students' progress in the academic field and co-curricular activities, students' discipline such 
as recording merit-demerit cards, etc. Apart from that, teachers need to work hard to meet the expectations of their school management, superiors, parents, students, education departments and the ministry of education.

Hence, over the years, many teachers are fuming and fretting about overburdened with responsibilities and workload. These teachers are also experiencing a lack of motivation and thus, they find it hard to cope with all the demands and expectations of the teaching profession. As a result, they become stressed out and if this condition continues without any proper remedies taken, it can lead to teacher burnout. Teacher burnout can lead to negative impacts not only on the teaching profession but also on students' education and the teachers' wellbeing. Are teachers really experiencing burnout today? If this is true, how serious is this problem and what are the symptoms of burnout among teachers? Is this issue applicable to both teachers in primary and secondary schools?

In relation to the above, it is claimed that primary and secondary school teachers in Malaysia suffered from stress (NUTP, 2005). Besides, research in Malaysia also indicates that teachers from different working experience categories suffer varying levels of burnout (Mukundan \& Khandehroo, 2009). All this provides evidence that today's teachers in Malaysia are also experiencing burnout to a certain level. According to a research conducted by the National Union of Teaching Profession (NUTP) about teacher stress, this issue needed to be investigated, including the sources of stress and the effect this had on teachers (Abdul Muin Sapidin, 2005). The NUTP (2005) proposed that this study must be performed because there were complaints about teacher stress and workload. Therefore, a study should examine the elements that contribute towards teacher stress, teachers' workload, issues surrounding fellow colleagues, parents, the school environment, students and the society. These gaps in the literature have triggered the researchers to conduct this study at one particular semi-urban primary school and one semi-urban secondary school in Samarahan District in Sarawak, Malaysia. Each of the researchers is teaching at the schools chosen and this has eased their efforts in administering the questionnaires. This topic has captured their interest as they have discovered through their random observation that some teachers are showing some symptoms of burnout and this needs to be ascertained further through this study.

\subsection{Research questions}

This study serves to answer the following research questions:

a) Do the teachers experience any symptoms of burnout?

b) Which category of burnout symptoms do the teachers experience the most and the least?

c) Does the teachers' period of service have any significant relationship with teacher burnout?

d) Does the teachers' subject option have any significant relationship with teacher burnout?

e) Does the school setting have any significant relationship with teacher burnout?

\subsection{Hypotheses}

This study also aims to test the following research hypotheses.

H1: There is a significant relationship between teachers' period of service and teacher burnout

H2: There is a significant relationship between the teachers' subject option with teacher burnout.

H3: There is a significant relationship between the school setting with teacher burnout.

\subsection{Significance of the study}

The findings obtained from this study are important in terms of its contribution to the teaching profession, the education departments, school managements and teachers themselves. With these findings, important information regarding teacher burnout can be obtained and suitable measures can be taken to overcome the problem. This study is especially significant to today's teachers who are continuously engaged with a lot of commitments at their place of work. Through the findings of this study, teachers would be able to identify the symptoms of teacher burnout experienced by teachers especially those experienced by the teachers in the two schools. Besides, when answering the questionnaire, teachers will be aware of teacher burnout and thus, this will encourage them to make efforts to control and manage their stress level in order to prevent themselves from experiencing burnout. Furthermore, this study will open opportunities for further future research.

\subsection{Limitation of the study}

This study involved only thirty-three respondents from one semi-urban primary and one semi-urban secondary school. Thus, the results of the study are only applicable to the teachers of the two schools and cannot be generalised to a bigger population.

\section{LITERATURE REVIEW}

Freudenberger (1974) defines burnout as a problem which involves feelings of failure and exhaustion resulting from excessive demands on a person's energy with insufficient reward for the effort. Other researchers have 
defined burnout as psychological distancing from work (Maslach, 1976). An online article entitled 'Preventing Burnout Signs, Symptoms, Causes, and Coping Strategies' by Helpguide Org. (2009) defines burnout as a state of emotional, mental and physical exhaustion caused by excessive and prolonged stress. It occurs when you feel overburdened and cannot fulfill constant demands. The stressful routine later causes the sufferers to lose the interest and motivation in discharging their duties. On the other hand, Carter (1994) defines teacher burnout as physical, emotional, and attitudinal exhaustion that begins with a feeling of uneasiness and mounts as the joy of teaching begins to gradually slip away.

Notably, there is a distinction between stress and burnout. Stress can have both positive and negative effects and in fact, a certain amount of stress is necessary to motivate action (Selye, 1976). In any human contact professions, every individual will have a certain amount of stress as it is unavoidable. Burnout is the final effect in a progression of unsuccessful attempts to cope with negative stress (Farber, 1984a). There are some early negative stress reactions experienced before teacher burnout which include apathy, displaced aggression on the pupils, feeling of exhaustion, frustration due to little sense of achievement, irritability and wanting to leave teaching (Dunham, 1992). Whatever the stress reactions, students will ultimately be the victims as the teaching and learning activities will be hampered.

Obviously, burnout does not happen overnight but it is a gradual process that occurs over an extended period of time. It can devour on you if you are not consciously paying attention to the warning signals. The signs and symptoms of burnout are difficult to detect at first, but they get worse and worse as time goes on. These early symptoms of burnout are warning signs which show that something is wrong and needs to be addressed. It is crucial to pay attention to these early warning signs to prevent a major breakdown. Ignoring them will eventually cause you to suffer from burnout. What are those signs and symptoms?

Studies by Lale (2001) and Posen (1995) found that many individuals who experienced chronic stress often developed physical symptoms including abdominal cramps and nausea, migraine headaches, and heart palpitations. In earlier studies, Block (1978) and Freudenberger (1983) cited in Mayben (2007) have identified many of the symptoms associated with burnout, which can be classified into three groups: physical (e.g., exhaustion, lingering cold, frequent headaches, gastrointestinal disturbances, weight loss, sleeplessness and shortness of breath), psychological ( e.g., changeable mood, irritability, depression, loss of caring for people, cynical attitude, increased frustration, feelings of helplessness, greater professional risk- taking [i.e., smoking, escapist drinking, drug use]), and behavioral (e.g., deterioration in work performance and absenteeism).

It is important to note that it is unlikely that any single isolated symptom can be viewed as an indication of burnout. But, the combination of various symptoms above and perhaps others represent the manifestations of burnout. Cheek et. al. (2003) cited that based on several international studies, approximately $60 \%$ to $70 \%$ of all teachers repeatedly show symptoms of stress, and a minimum of $30 \%$ of all educators show distinct symptoms of burnout (Antoniou, Polychroni, \& Walters, 2000; Borg \& Falzon, 1989; Capel, 1992; Kyriacou, 1980; Kytaev-Smyk, 1983; Lale, 2001; Rudow, 1999). In fact, Lumsden (1998) found that teacher morale overall was so low that $40 \%$ of teachers surveyed would not select teaching again as a career, and $57 \%$ were either undecided about leaving teaching, actively planning to leave teaching, or would leave the teaching field if something better came along. This situation is serious as such a high percentage of teachers complained about burnout. It would affect the quality of teaching and the quality of life among teachers.

There is a great concern over significant numbers of stressed and burned out teachers in recent years. The effects of burnout can be devastating. There is a lot of evidence that prolonged occupational stress can lead to both mental and physical ill-health, and can significantly vitiate the teacher-pupil relationship and the quality of teaching (Kyriacou, 1987). The Ministry of Education, educationists, and the general public have all expressed their concerned over this issue. Stress and burnout not only influence teachers' professional lives, but also impact their mental and physical well-being. In a study conducted in the Netherlands, 53\% of workincapacitated teachers left their profession because they suffered from mental health problems (Algemeen burgerlijk pensioenfonds, 1995). If these issues are not addressed, eventually, the individual loses desire and motivation, and is unable to cope with, fight or flee from the pressing situation. If worsen, it can lead to a more devastating effects on the individual, the school, and students. Therefore, conducting this study is vital to obtain authentic information about the conditions of teachers' physical, emotional, mental and psychological state which can show whether they are showing any level of teacher burnout.

\section{METHODOLOGY}

\subsection{Sample}

The respondents for the study were fifty teachers ( 25 teaching at a primary school and 25 were teaching at a secondary school). The school names are kept anonymous and only classified in this study as School A (Primary School) and School B (Secondary School). A Simple Random Sampling was used to select the sample for this study. Name lists of teachers were taken from each school. The whole population is grouped according to their school and then the numbers (written on a piece of paper according to the name lists) were drawn from each 
group/school. School A (Primary School) has a population of 64 teachers (8 males \& 56 females), while School B (Secondary School) has a population of 124 teachers ( 24 males \& 100 females) The teachers were between 26 to 53 years old. However, only 16 respondents from school A and 17 respondents from school B returned their questionnaires. Hence, the data collected was based on the 33 respondents and not 50 as planned earlier. The selected respondents of School A (Primary School) were made up of 7 males and 9 females while the selected respondents of School B (Secondary School) were made up of 12 females and 5 males. A majority of the teachers had heard of burnout and only 3 had not.

\subsection{Data collection method}

A Survey design using a questionnaire as a data collection tool was employed in this study. This type of design is used as it allows data to be collected in a standardized way from a large sample in a short period of time and it is also more objective in its results than other methods such as interviews (Milne, 1999). The questionnaire was adapted from Maslach Burnout Inventory (1982) focusing mainly on the 4 categories of teacher burnout symptoms namely emotional exhaustion, physical exhaustion, depersonalisation and reduced personal accomplishment. It is rated according to Likert scales; 1 as Never and 5 as always, and it is divided into 2 sections: Section A for a demographic of the respondents and Section B for the symptoms of teacher burnout. The questionnaires were distributed randomly to 50 teachers and they were given the freedom to complete it at their own convenient time.

\subsection{Data Analysis Procedures}

The SPSS version 17.0 was used for statistical analysis. Descriptive statistics namely frequencies such as percentage, minimum, maximum, mean and standard deviation were employed to answer the research questions $1 \&$ 2: Do the teachers experience any symptoms of burnout? and Which category of burnout symptoms do the teachers experienced the most and the least? Inferential statistics such as the Spearman's Rho Correlation Coefficient was used to answer research questions 3 and 4: Does the teachers' period of service have any significant relationship with teacher burnout? and Does the subject option have any significant relationship with teacher burnout? Finally, to answer the fifth research question "Does the school setting have any significant relationship with teacher burnout?" Chi-square was used. The data obtained was presented in the form of tables and scatter plots and the findings were generated.

\section{RESULTS OF THE STUDY}

4.1. Do the teachers experience any symptoms of burnout?

Table 1: Symptoms of teacher burnout

\begin{tabular}{llrrrr}
\hline & & $\begin{array}{c}\text { emotional } \\
\text { exhaustion }\end{array}$ & $\begin{array}{c}\text { Physical } \\
\text { exhaustion }\end{array}$ & $\begin{array}{c}\text { Depersonalisa } \\
\text { tion }\end{array}$ & $\begin{array}{c}\text { Reduced personal } \\
\text { accomplishment }\end{array}$ \\
\hline $\mathrm{N}$ & Valid & 32 & 32 & 32 & 32 \\
& Missing & 1 & 1 & 1 & 1 \\
Minimum & & 2.00 & 1.67 & 1.00 & 1.00 \\
Maximum & 5.00 & 4.67 & 4.22 & 3.40 \\
Sum & 102.00 & 85.33 & 83.44 & 69.00 \\
Percentiles & 100 & 5.0000 & 4.6667 & 4.2222 & 3.4000 \\
\hline
\end{tabular}

Table 1 above shows that the teachers of the two schools were experiencing a moderate level of symptoms of teacher burnout. From the 33 respondents, about 50\% were showing symptoms of emotional exhaustion, $47 \%$ were showing symptoms of physical exhaustion, $42 \%$ were showing symptoms of depersonalisation and $34 \%$ were showing symptoms of reduced personal accomplishment. This answers the first research question that the teachers of the two schools showed a moderate level of teacher burnout.

4.2. Which category of burnout symptoms do the teachers experience the most and the least?

The above Table 1 also provides an answer for the second research question. Apparently, the most symptom experienced by the teachers was emotional exhaustion with a percentage of $50 \%$. There were only two items for this category of symptoms - 'I am feeling tired and drained' and 'I am feeling sick a lot.' 


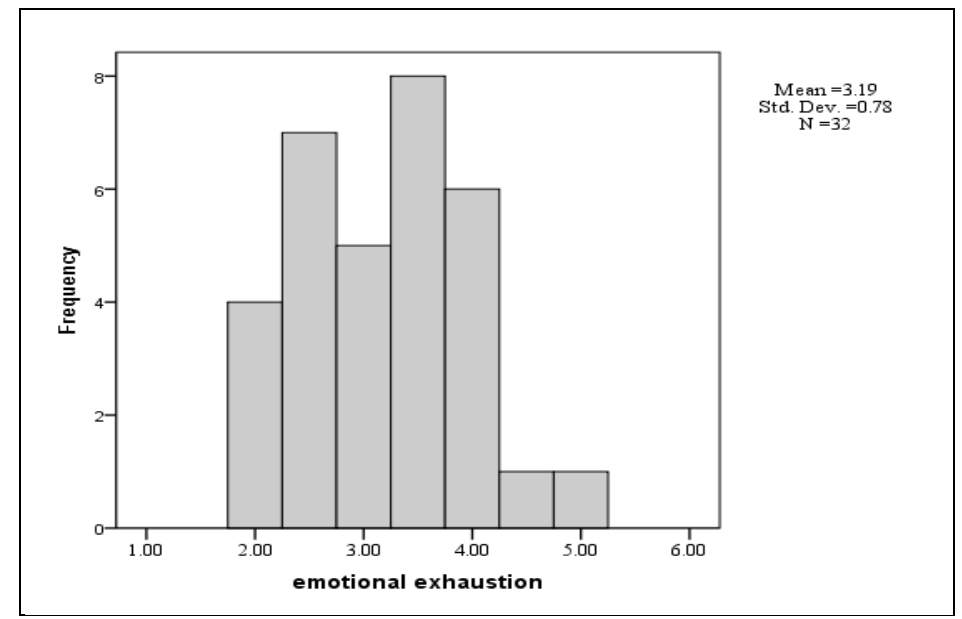

Figure 1: Emotional exhaustion

As can be seen in Fig. 1 above, a majority of the respondents rated a moderate rating of ' 3 - sometimes' for emotional exhaustion symptoms as the mean was equal to $3.19(S D=.78)$. Hence, the teachers of the two schools were moderately affected emotionally in their work such as feeling tired and drained and sick a lot. Slightly lower than emotional symptom, the second highest symptom the respondents experienced was physical exhaustion that constituted $47 \%$. There were three items under this category: 'I have headaches, back pain and muscle aches, 'I experience a change in appetite or sleep habits' and 'Nothing I do make a difference or is appreciated'.

Fig. 2 below shows that a majority of the respondents rated their physical exhaustion as ' 2 - rarely' and ' 3 sometimes'. This is ascertained as it is also shown that it had an average mean of $2.67(S D=.85)$ indicating that the teachers were showing a moderate symptom of physical exhaustion of teacher burnout.

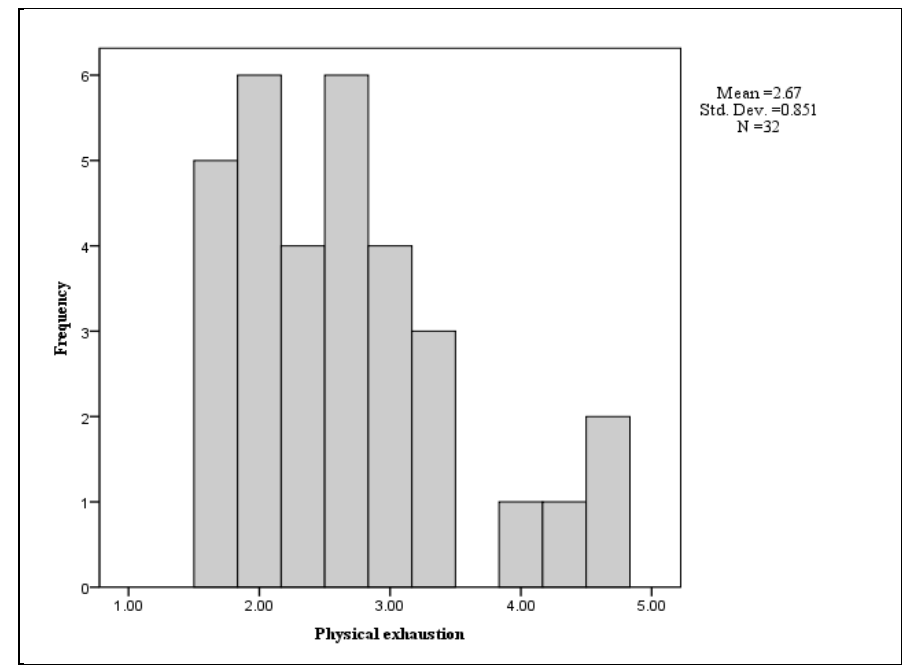

Figure 2: Physical exhaustion

The third highest category of symptoms showed by the teachers was depersonalisation with a percentage of $42 \%$, an average mean of $2.61(S D=.83)$. It is an average level of rating of the teachers' depersonalisation symptom shown whereby a majority of the respondents rated each of the 9 items as ' 2 - rarely' and ' 3 sometimes'. However, Table 1 and Fig. 3 show that the minimum scale rated was ' 1 - Never' and the maximum is ' 4 - Very often'. Among the symptoms of depersonalisation are 'I experience a sense of failure and selfdoubt', 'I am feeling helpless, trapped and defeated', 'I am feeling alone', I lost motivation in doing my work', etc. 


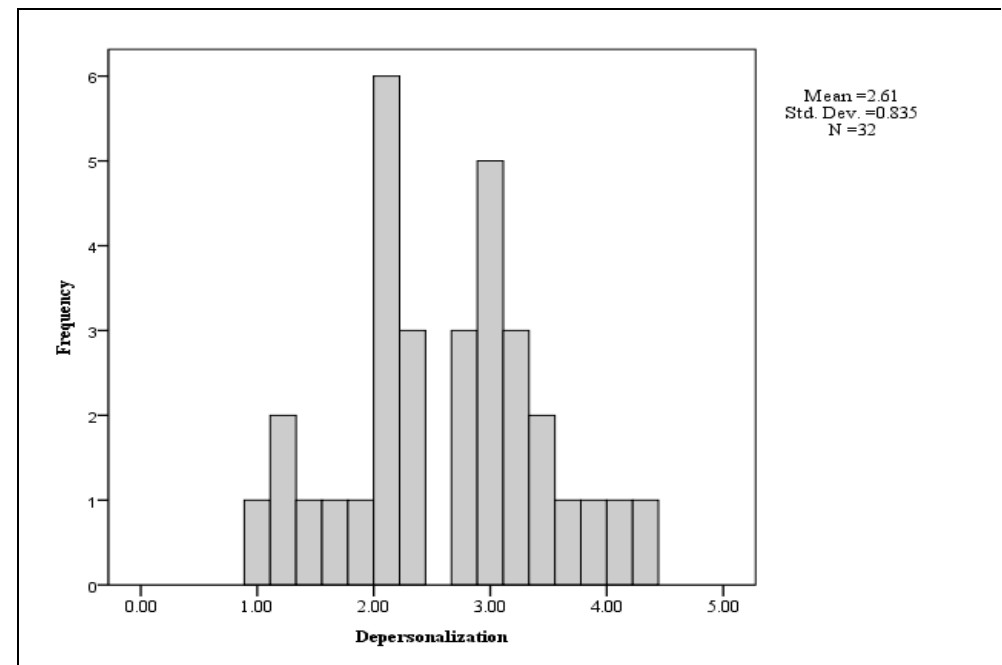

Figure 3: Depersonalisation

The least category of teacher burnout symptoms experienced by the respondents was reduced personal accomplishment with a percentage of $34 \%$. There are 5 items (symptoms) classified under this category which include 'I want to withdraw from my responsibilities', 'I take out my frustrations on others such as my family, students, friends or colleagues', 'I skip work or come in late and leave early', 'Every day is a bad day for me', and 'The majority of my day is spent on tasks I find either mind-numbingly dull or overwhelming'.

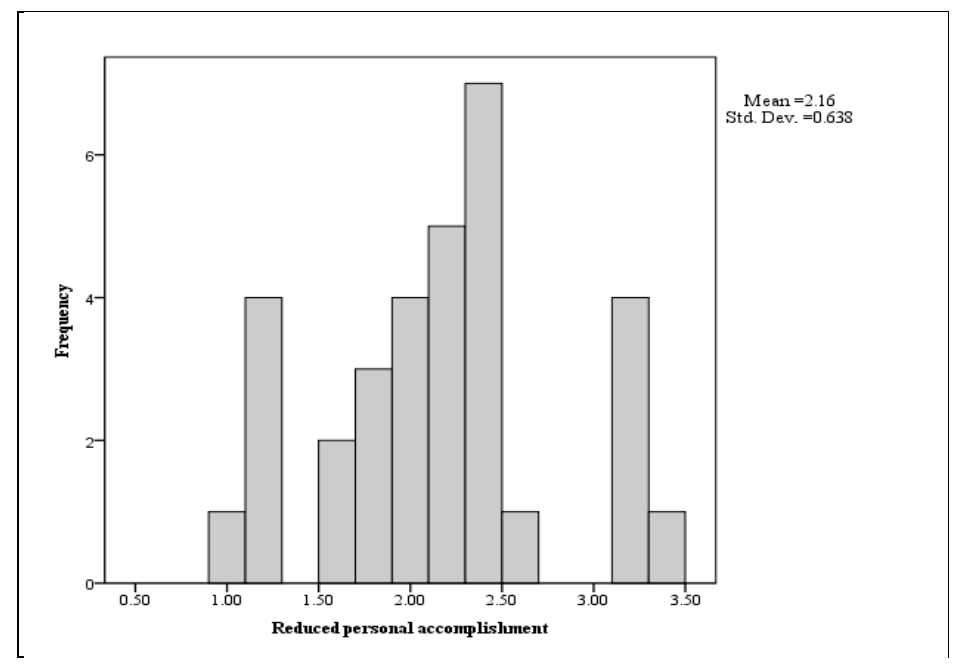

Figure 4: Reduced personal accomplishment

This category of symptoms (Fig.4) shows an average frequency mean of $2.16(S D=.63)$ which shows that most of the respondents rated their responses as ' 2 - rarely'. Only one respondent rated his/her response as ' 3 Sometimes'. This reveals that teachers were rarely affected in terms of their personal accomplishment in connection to teacher burnout.

4.3. Does teachers' period of service have any significant relationship with teacher burnout?

Table 2 below shows that 12 teachers have a period of service or teaching experience of between $16-19$ years, 10 have between $9-15$ years, 8 have between 21-31 years and only 2 have 5 and 7 years respectively. Based on the data obtained, it is noticed that all the teachers are without doubt experienced teachers in terms of the number of years of their teaching experience.

Table 2: Period of Service

\begin{tabular}{lcccc}
\hline Period of & Frequenc & & Valid & Cumulative \\
Service & $\mathrm{y}$ & Percent & Percent & Percent \\
\hline
\end{tabular}




\begin{tabular}{lrrrrr}
\hline Valid & 31.00 & 2 & 6.1 & 6.3 & 6.3 \\
& 23.00 & 2 & 6.1 & 6.3 & 12.5 \\
& 22.00 & 2 & 6.1 & 6.3 & 18.8 \\
& 21.00 & 2 & 6.1 & 6.3 & 25.0 \\
& 19.00 & 5 & 15.2 & 15.6 & 40.6 \\
& 18.00 & 5 & 15.2 & 15.6 & 56.3 \\
& 16.00 & 2 & 6.1 & 6.3 & 62.5 \\
15.00 & 2 & 6.1 & 6.3 & 68.8 \\
& 13.00 & 3 & 9.1 & 9.4 & 78.1 \\
& 10.00 & 2 & 6.1 & 6.3 & 84.4 \\
& 9.00 & 3 & 9.1 & 9.4 & 93.8 \\
& 7.00 & 1 & 3.0 & 3.1 & 96.9 \\
& 5.00 & 1 & 3.0 & 3.1 & 100.0 \\
& Total & 32 & 97.0 & 100.0 & \\
\hline Missing & System & 1 & 3.0 & & \\
Total & 33 & 100.0 & & \\
\hline
\end{tabular}

To examine whether there is any significant relationship between the teachers' period of service and teacher burnout, the Spearman's Rho Correlation Coefficient was employed for the data analysis.

Table 3: The Correlation between period of service and teacher burnout

\begin{tabular}{|c|c|c|c|c|c|c|}
\hline & & & $\begin{array}{r}\text { Emotional } \\
\text { exhaustion }\end{array}$ & $\begin{array}{r}\text { Physical } \\
\text { exhaustion }\end{array}$ & $\begin{array}{r}\text { Depersona } \\
\text { lisation }\end{array}$ & $\begin{array}{r}\text { Reduced personal } \\
\text { accomplishment }\end{array}$ \\
\hline \multirow[t]{3}{*}{$\begin{array}{l}\text { Spearman } \\
\text { 's rho }\end{array}$} & \multirow{3}{*}{$\begin{array}{l}\text { Period } \\
\text { of } \\
\text { Service }\end{array}$} & $\begin{array}{l}\text { Correlation } \\
\text { Coefficient }\end{array}$ & $.490^{* *}$ & $.419^{*}$ & $.508^{* *}$ & .341 \\
\hline & & $\begin{array}{l}\text { Sig. (2- } \\
\text { tailed) }\end{array}$ & .004 & .017 & .003 & .056 \\
\hline & & $\mathrm{N}$ & 32 & 32 & 32 & 32 \\
\hline
\end{tabular}

**. Correlation is significant at the 0.01 level (2-tailed).

*. Correlation is significant at the 0.05 level (2-tailed).

Table 3 shows that there was a significant relationship between teachers' period of service and teacher burnout with $p<.05$ for all other categories of burnout symptoms except for reduced personal accomplishment. However, there were weak and moderate positive correlations between teachers' period of service or teaching experience and the four categories of teacher burnout (with weak positive correlations of $r=.49$ for emotional exhaustion, $r=.42$ for physical exhaustion and $r=.34$ for reduced personal accomplishment and with a moderate positive correlation of $r=.51$ for depersonalisation. Thus, this analysis provides enough evidence to reject the null hypothesis which denotes that the longer the number of years the teachers has taught the more likely they are experiencing burnout. This can be explained further by looking at the correlation coefficient of the teachers' period of service with each category of teacher burnout symptoms and their scatter plots.

Table 4: The Correlation between period of service and emotional exhaustion

\begin{tabular}{lllrr}
\hline & & $\begin{array}{c}\text { teaching } \\
\text { experience }\end{array}$ & $\begin{array}{c}\text { Emotional } \\
\text { exhaustion }\end{array}$ \\
\hline Spearman's rho & Period of & Correlation Coefficient & 1.000 & $.490^{* *}$ \\
& service & Sig. (2-tailed) &. & .004 \\
& & $\mathrm{~N}$ & 32 & 32 \\
& emotional & Correlation Coefficient & $.490^{* * *}$ & 1.000 \\
& exhaustion & Sig. (2-tailed) & .004 &. \\
& & $\mathrm{~N}$ & 32 & 32 \\
\hline
\end{tabular}

**. Correlation is significant at the 0.01 level (2-tailed). 


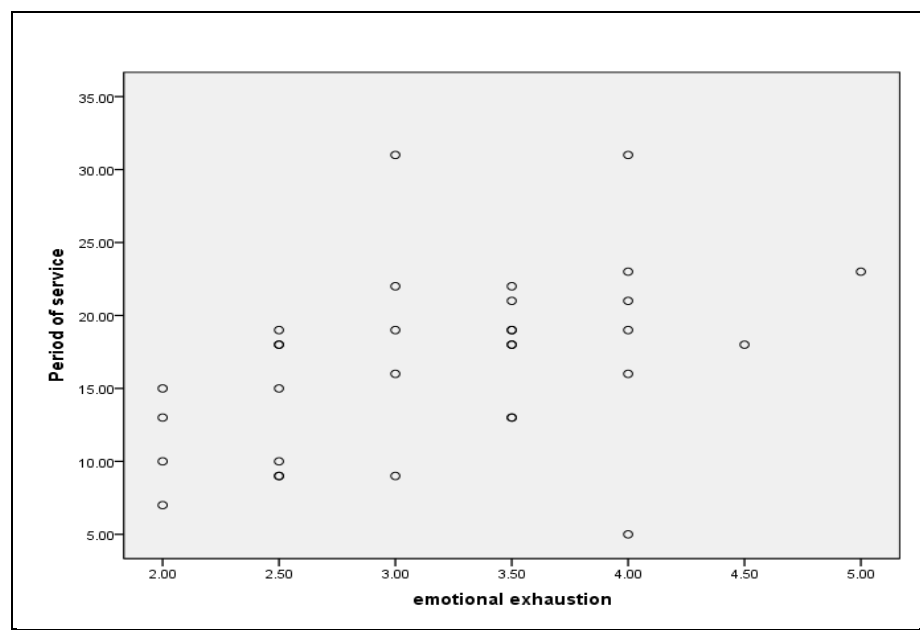

Figure 5: The correlation between period of service and emotional exhaustion

Table 4 shows that teachers' period of service had a weak positive correlation of $r=.49$ with teachers' emotional exhaustion. The relationship was significant with the $p=.004$. This correlation coefficient is visualised in the form of a scatter plot in Fig. 5. Thus, this analysis shows that the longer the number of years the teachers has taught the more likely they are exhibiting the symptoms of emotional exhaustion such as feeling tired and drained, feeling sick a lot, etc.

Table 5: The correlation between period of service and physical exhaustion

\begin{tabular}{|c|c|c|c|c|}
\hline & & & $\begin{array}{l}\text { teaching } \\
\text { experience }\end{array}$ & $\begin{array}{l}\text { Physical } \\
\text { exhaustion }\end{array}$ \\
\hline \multirow[t]{6}{*}{$\begin{array}{l}\text { Spearman's } \\
\text { rho }\end{array}$} & \multirow[t]{3}{*}{$\begin{array}{l}\text { Period of } \\
\text { Service }\end{array}$} & $\begin{array}{l}\text { Correlation } \\
\text { Coefficient }\end{array}$ & 1.000 & $.419^{*}$ \\
\hline & & Sig. (2-tailed) & . & .017 \\
\hline & & $\mathrm{N}$ & 32 & 32 \\
\hline & \multirow[t]{3}{*}{$\begin{array}{l}\text { Physical } \\
\text { exhaustion }\end{array}$} & $\begin{array}{l}\text { Correlation } \\
\text { Coefficient }\end{array}$ & $.419^{*}$ & 1.000 \\
\hline & & Sig. (2-tailed) & .017 & \\
\hline & & $\mathrm{N}$ & 32 & 32 \\
\hline
\end{tabular}

Table 5 above shows that there was a weak positive correlation of $r=.41$ between teaching experience and teachers' physical exhaustion. The relationship was significant with the $p=.017$ and this implies that the longer the number of teaching experience, the more it affects teachers' physical well-being such as having headaches, back pain, muscle aches, experience a change in appetite or sleep habits, etc. This correlation pattern can be seen in the scatter plot of Fig. 6. 


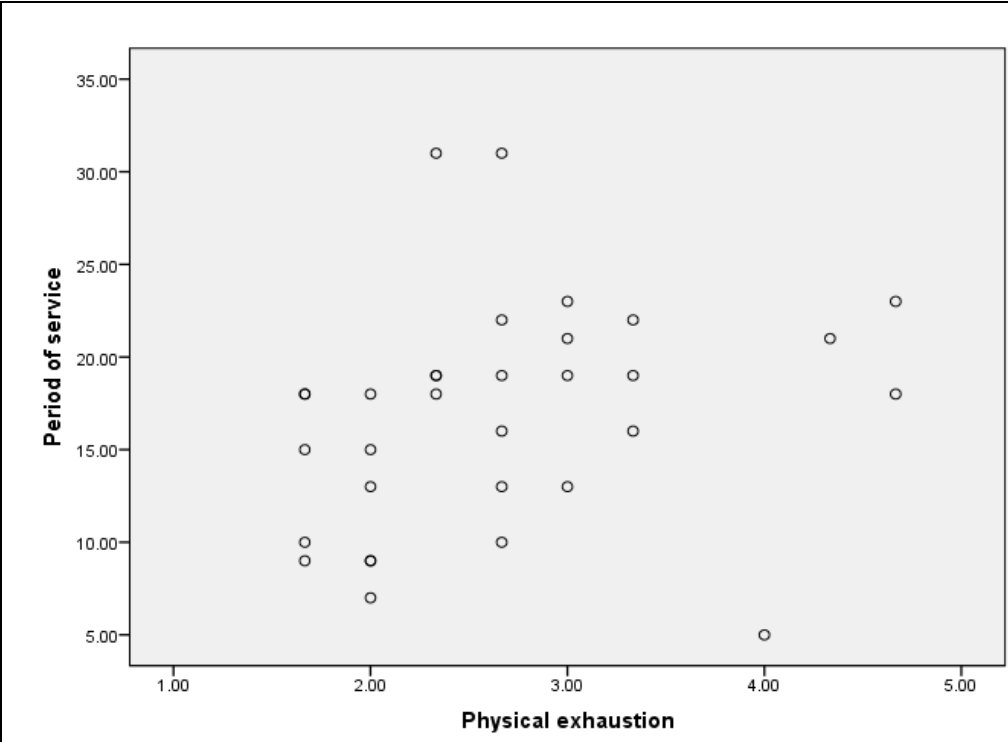

Figure 6: The correlation between period of service and physical exhaustion

Table 6: The correlation between period of service and depersonalisation

\begin{tabular}{|c|c|c|c|c|}
\hline & & & $\begin{array}{l}\text { teaching } \\
\text { experience }\end{array}$ & Depersonalisation \\
\hline \multirow[t]{6}{*}{$\begin{array}{l}\text { Spearman' } \\
\text { s rho }\end{array}$} & \multirow[t]{3}{*}{ Period of Service } & $\begin{array}{l}\text { Correlation } \\
\text { Coefficient }\end{array}$ & 1.000 & $.508^{* * *}$ \\
\hline & & Sig. (2-tailed) & . & .003 \\
\hline & & $\mathrm{N}$ & 32 & 32 \\
\hline & \multirow[t]{3}{*}{ Depersonalisation } & $\begin{array}{l}\text { Correlation } \\
\text { Coefficient }\end{array}$ & $.508^{* * *}$ & 1.000 \\
\hline & & Sig. (2-tailed) & .003 & \\
\hline & & $\mathrm{N}$ & 32 & 32 \\
\hline
\end{tabular}

**. Correlation is significant at the 0.01 level (2-tailed).

Table 6 above shows a moderate positive correlation of $r=.51$ between period of service and teachers' depersonalisation symptoms. This relationship was significant with the $p=.003$. This moderately positive correlation coefficient shows that the longer the teaching experience the teachers have, the more depersonalised they become. This can be visualised in the following scatter plot of Fig. 7.

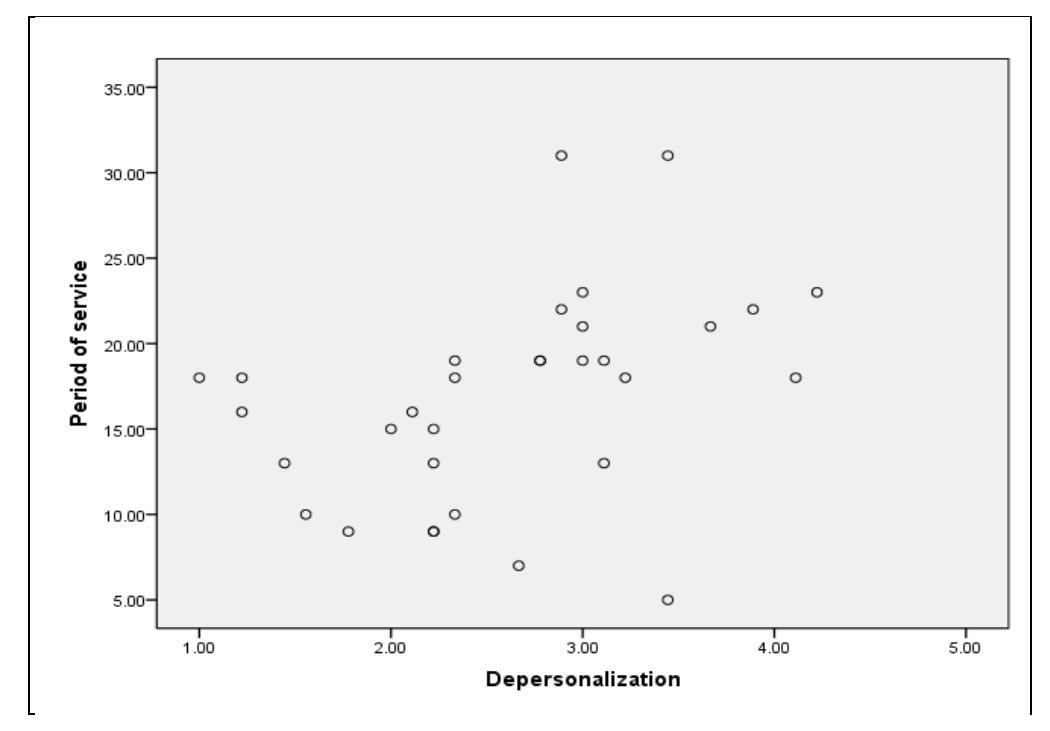


Figure 7: The correlation between period of service and depersonalisation

Table 7: The correlation between period of service and reduced personal accomplishment.

\begin{tabular}{llrrr}
\hline & & & $\begin{array}{c}\text { Period of } \\
\text { Service }\end{array}$ & $\begin{array}{c}\text { Reduced personal } \\
\text { accomplishment }\end{array}$ \\
\hline $\begin{array}{l}\text { Spearman's } \\
\text { rho }\end{array}$ & $\begin{array}{l}\text { Period of } \\
\text { Service }\end{array}$ & Correlation & 1.000 & .341 \\
& Coefficient & & .056 \\
& Sig. (2-tailed) &. & 32 \\
& $\mathrm{~N}$ & .341 & 1.000 \\
& Reduced & Correlation & & \\
personal & Coefficient & .056 & 32 \\
\hline & accomplishment & Sig. (2-tailed) & 32 & \\
& $\mathrm{~N}$ & & \\
& & & &
\end{tabular}

Table 7 above shows that there is a weak positive correlation of $r=.34$ between period of service with reduced personal accomplishment. However, the relationship was not significant as the $p=.56$. Therefore, this implies that teachers' period of service did not have any significant influence on teachers' reduced personal accomplishment. This correlation can be visualised in the scatter plot of Fig. 8.

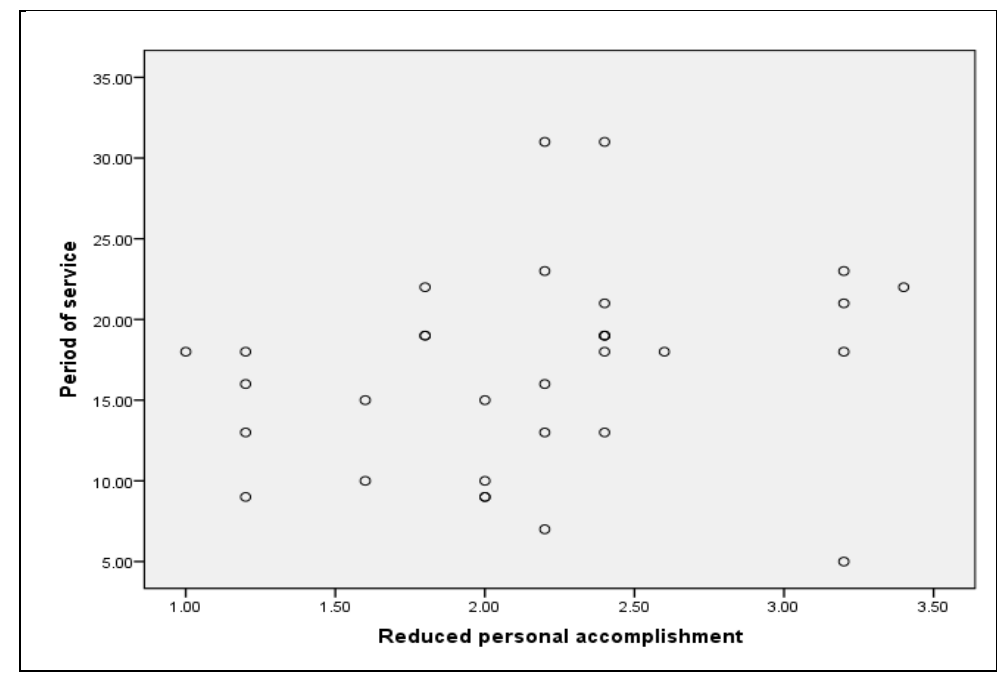

Table 8: The correlation between period of service and reduced personal accomplishment

Notably, at the significant level of $\mathrm{p}<.05$, the above statistical analysis shows that there was a significant relationship between period of service and teacher burnout. There were weak and moderate positive correlation between period of service or teaching experience and three categories of teacher burnout symptoms (emotional exhaustion, physical exhaustion and depersonalisation) except for reduced accomplishment. Thus, teachers' period of service or teaching experience had a slight effect on teacher burnout, meaning that the longer their teaching experience, the higher the possibility of teachers showing symptoms of teacher burnout.

4.4. Does the teachers' subject option have significant relationship with teacher burnout?

Table 8: The correlation between teachers' subject option and teacher burnout.

\begin{tabular}{|c|c|c|c|c|c|c|c|}
\hline & & & $\begin{array}{l}\text { Subject } \\
\text { option }\end{array}$ & $\begin{array}{l}\text { Emotional } \\
\text { exhaustion }\end{array}$ & $\begin{array}{l}\text { Physical } \\
\text { exhaustion }\end{array}$ & $\begin{array}{l}\text { Depersonali } \\
\text { zation }\end{array}$ & $\begin{array}{l}\text { Reduced personal } \\
\text { accomplishment }\end{array}$ \\
\hline \multirow[t]{3}{*}{$\begin{array}{l}\text { Spearman' } \\
\text { s rho }\end{array}$} & $\begin{array}{l}\text { Subject } \\
\text { option }\end{array}$ & $\begin{array}{l}\text { Correlation } \\
\text { Coefficient }\end{array}$ & 1.000 & -.058 & .071 & -.079 & -.030 \\
\hline & & $\begin{array}{l}\text { Sig. (2- } \\
\text { tailed) }\end{array}$ & . & .752 & .698 & .668 & .870 \\
\hline & & $\mathrm{N}$ & 32 & 32 & 32 & 32 & 32 \\
\hline
\end{tabular}


Table 8: The correlation between teachers' subject option and teacher burnout.

\begin{tabular}{|c|c|c|c|c|c|c|c|}
\hline & & & $\begin{array}{l}\text { Subject } \\
\text { option }\end{array}$ & $\begin{array}{l}\text { Emotional } \\
\text { exhaustion }\end{array}$ & $\begin{array}{l}\text { Physical } \\
\text { exhaustion }\end{array}$ & $\begin{array}{l}\text { Depersonali } \\
\text { zation }\end{array}$ & $\begin{array}{l}\text { Reduced personal } \\
\text { accomplishment }\end{array}$ \\
\hline \multirow[t]{3}{*}{$\begin{array}{l}\text { Spearman' } \\
\text { s rho }\end{array}$} & $\begin{array}{l}\text { Subject } \\
\text { option }\end{array}$ & $\begin{array}{l}\text { Correlation } \\
\text { Coefficient }\end{array}$ & 1.000 & -.058 & .071 & -.079 & -.030 \\
\hline & & $\begin{array}{l}\text { Sig. (2- } \\
\text { tailed) }\end{array}$ & - & .752 & 698 & .668 & .870 \\
\hline & & $\mathrm{N}$ & 32 & 32 & 32 & 32 & 32 \\
\hline
\end{tabular}

**. Correlation is significant at the 0.01 level (2-tailed).

Table 8 shows that there was a moderate negative correlation between teachers' subject option with most of the categories of teacher burnout except with physical exhaustion which showed a moderate positive correlation. However, the relationships were not significant. The table shows that teachers' subject option had a moderately negative correlation of $r=-.058(\mathrm{n}=32, p=.75)$ with emotional exhaustion symptoms of teacher burnout, a strong negative correlation of $r=-.079(\mathrm{n}=32, p=.66)$ with depersonalisation symptoms, a weak negative correlation of $r=-.03(\mathrm{n}=32, p=.87)$ with reduced personal accomplishment and a strong positive correlation of $r=.71(\mathrm{n}=32, p=.69)$ with physical symptoms of teacher burnout. Therefore, there is not enough evidence to reject the null hypothesis, denoting that the teachers' subject option does not have any strong influence on teacher burnout. This analysis shows that the teachers' subject option does not affect teachers' emotional state, personality and accomplishment and physical well being.

4.5. Does the school setting have any significant relationship with teacher burnout?

Table 9: School setting and teacher burnout

\begin{tabular}{lrrrrr}
\hline & $\begin{array}{c}\text { School } \\
\text { setting }\end{array}$ & $\begin{array}{c}\text { Emotional } \\
\text { exhaustion }\end{array}$ & $\begin{array}{c}\text { Physical } \\
\text { exhaustion }\end{array}$ & $\begin{array}{c}\text { Deper- } \\
\text { sonalisation }\end{array}$ & $\begin{array}{c}\text { Reduced } \\
\text { personal } \\
\text { accomplishment }\end{array}$ \\
\hline Chi-Square &. & $10.000^{\mathrm{b}}$ & $8.500^{\mathrm{c}}$ & $9.250^{\mathrm{d}}$ & $11.125^{\mathrm{e}}$ \\
df & 1 & 6 & 8 & 19 & 9 \\
Asymp. Sig. & 1.000 & .125 & .386 & .969 & .267 \\
\hline
\end{tabular}

a. 0 cells $(.0 \%)$ have expected frequencies less than 5 . The minimum expected cell frequency is 16.0 .

b. 7 cells $(100.0 \%)$ have expected frequencies less than 5 . The minimum expected cell frequency is 4.6 .

c. 9 cells $(100.0 \%)$ have expected frequencies less than 5. The minimum expected cell frequency is 3.6 .

d. 20 cells $(100.0 \%)$ have expected frequencies less than 5 . The minimum expected cell frequency is 1.6 .

e. 10 cells $(100.0 \%)$ have expected frequencies less than 5 . The minimum expected cell frequency is 3.2 .

Table 9 shows the Chi-square between school setting and teacher burnout. Apparently, all the cells (categories) have expected frequencies less than 5. So the assumption has been unsatisfied. Specifically, at 5\% significant level, the value of the Chi-square statistic for school setting and emotional exhaustion was 10.00, a $d f=6$ and $p$ $=.13$ which is bigger than .05 . So, there was no significant difference between school setting and emotional exhaustion. This shows that the school setting did not affect teachers' emotional exhaustion. Next, there was also no significant relationship between school setting and physical exhaustion symptoms with a Chi-square of 8.50, a $d f=8$ and a $p=.39$ ( $p$-value is more than .05). School setting and depersonalisation also did not have any significant difference with $p=.96, d f=19$ and a chi-square of 9.25 . Hence, this reveals that school setting did not have strong influence on depersonalisation of teachers. There was also no significant relationship between school setting and reduced personal accomplishment with a chi-square of $11.12, d f=9$ and $p=.26$. Thus, this shows that the school where the teachers are teaching does not have any significant or strong influence on the reduced personal accomplishment of the respondents. 
All this analysis reveals that there was no significant relationship or correlation between school setting and teacher burnout experienced by the teachers from both schools. In other words, the school setting did not have any significant effects on teacher burnout.

\section{DISCUSSION}

The teachers of the two schools experienced a moderate level of burnout symptoms as discussed in the results of the study. Among the four categories of burnout symptoms included in the questionnaire, the teachers showed the most symptoms of emotional exhaustion, followed by physical exhaustion and depersonalisation, and reduced personal accomplishment as the least symptom showed. The results of this present study significantly portrayed that the symptoms showed by the respondents were due to work-related factors such as heavy workload, high demands or expectation from administrators, etc which could lead to emotional exhaustion, physical exhaustion and depersonalisation which are congruent with past studies (Eker \& Anbar, 2008; Mukundan \& Khandehroo, 2010). Despite the heavy responsibilities, the teachers from the two schools were not seriously affected in terms of their personal accomplishment or commitment towards their job. Although emotionally they were moderately affected, only $34 \%$ were affected in terms of reduced personal accomplishment which showed that a majority of them still showed a positive attitude by being committed despite the heavy responsibilities that they had to shoulder.

Another reason for the low level of reduced personal accomplishment symptoms among the participants might be due to a positive relationship among the teachers in the two schools. As the researchers are teaching at these schools, they noticed for example that there exist a positive collaboration and collegiality among the teachers and between the teachers and the administrative staff. Besides, the school managements of both schools also carry out professional development programme at least once a year involving all their staff. This has also helped in one way or another to reduce stress and prevent burnout among the teachers.

Thus, according to the results of the present study analyses, factors related to demographic characteristics such as subject option and school setting did not have any significant relationship with teacher burnout. There was no significant relationship and moderate negative correlations between subject option and three categories of teacher burnout symptoms except for physical exhaustion which had a moderate positive correlation. Therefore, the teachers' subject option did not have any strong influence on teacher burnout. Apart from that, there was also no significant relationship between the school setting and the symptoms of teacher burnout experienced by the teachers from both schools. This revealed that the school setting did not have any significant effects or influence on teacher burnout which was inconsistent with the results of past studies by Byrne (1999) and Maslach, Schjaufeli \& Leiter (2001). The school setting may include the students' background, administrative staff, parents, physical facilities of the schools, expectations from the administration, community, etc. Teachers of the two schools were not affected by the school setting probably because of the conducive working environment of the two schools.

The statistical analysis showed that only teachers' period of service had significant but weak and moderate positive correlations with three categories of teacher burnout symptoms. This seems to portray that teachers tend to get worn out after teaching many years in schools and facing a mundane routine daily in their teaching career. This ascertains a claim that research in Malaysia also indicates that teachers from different working experience categories suffer varying levels of burnout (Mukundan \& Khandehroo, 2009). A majority of the teachers selected for this study are between 35-55 years old and have taught between $10-23$ years at the respective schools. Thus, this present study reveals that senior or older teachers also show symptoms of burnout to a certain level especially in terms of emotional exhaustion, physical exhaustion and depersonalisation. Thus, this is a pertinent finding which revealed that teachers' period of service or years of teaching experience had a significant relationship with teacher burnout.

Nevertheless, there are some limitations of the study. The results of this study cannot be generalised to a bigger population or to teachers of other schools as only a small sample of thirty-three teachers was used and only two schools were involved in this study. Using a bigger sample was not possible in the present study because many selected respondents (17 teachers) did not return their questionnaires. This was probably because they were reluctant to reveal about their personal life although they were informed that the information would be kept confidential. Hence, it is recommended that future researchers should use bigger sample in order to obtain more conclusive results and can generalise them to a bigger population. Besides, future researchers should also compare relationship between gender and teacher burnout as in this study it could not be done due to the different number of sample in terms of gender as it was overlooked by the researchers prior to the study. Apart from that, future researchers can also conduct a comparative study on teacher burnout between primary and secondary school teachers by comparing demographic characteristics such as school setting, gender, subject option, period of service, age, etc.

\section{CONCLUSION}


The results of this study have some significant implications. First, they ascertained the findings of past studies that today's teachers are experiencing symptoms of burnout such as emotional exhaustion, physical exhaustion, depersonalisation and reduced personal accomplishment to a certain level. Next, they provide important insights and information about the level of burnout among teachers at the two semi-urban schools (primary and secondary) in Samarahan District. It was discovered that the teachers of the two schools were not seriously affected by burnout as there was only a moderate level of teacher burnout symptoms shown. In contrast with findings by past studies, it was also found that the teachers' subject option and school setting did not have any significant relationships with teacher burnout. This is another significant implication of the results that school setting which includes the students' background, administrative staff, parents, physical facilities of the schools, community, etc. did not have any significant relationship or effect on teacher burnout. Teachers of the two schools were not affected by the school setting probably because of the conducive working environment of the two semi-urban schools. However, it was found that only teachers' period of service or teaching experience had significant relationship with teacher burnout. This ascertains the claim that teachers in Malaysia who are from different working experience categories suffer varying levels of burnout. Despite a moderate level of teacher burnout experienced by the teachers of the present study, positive measures need to be taken by relevant parties such as the district education department and school management to tackle this phenomenon before it becomes serious. School management can organise effective programmes such as a staff professional development programme, conduct seminars or talks on stress management, motivation, awareness on teacher burnout, etc. to counsel, inspire and motivate teachers. Through all this, the level of teachers' stress and burnout symptoms will be kept under control and teacher burnout can be avoided to develop an excellent teaching career in the $21^{\text {st }}$ century.

\section{ACKNOWLEDGEMENTS}

We would like to express our heartiest gratitude to the headmaster and the principal of the two schools for allowing us to conduct this research among the teachers of their schools. We would like to thank the teachers too for their willingness to be the respondents of this study and their cooperation in answering the questionnaires.

\section{REFERENCES}

[1] Juriani Jamaludin \& Ghaziah Mohd Ghazali. Job satisfaction and stress among secondary school music teachers in Malaysia. Malaysian Music Journal, 1(2) 2013, 72-86.. Mayben. (2008). Teacher burnout action research [online]. Available: http://www.bama.ua.edu/ rmayben/edbio1.htm\#_Hlk26863998

[2] Abd. Suseela Malakolunthu, A Study of teacher stress and its correlates, unpublished master's thesis, University of Malaya, 1994.

[3] Junaidah Abd. Jamil, Perceived teachers' stress in selected secondary school In Kuala Lumpur, unpublished master's thesis, Universiti Malaya, 1995.

[4] Mohd Razali Othman \& Abg Mat Ali Abg Masagus. (1998). Strategi menangani tekanan di kalangan guru-guru Sekolah Menengah

[5] Zon A di Bahagian Kuching: Satu tinjauan, paper presented in Program Seminar Pendidikan Sempena Perayaan Jubli Emas Maktab

[6] PerguruanBatuLintang[online].Available:http://s4.invisionfree.com/wantar/ar/t105.http://devadason.tripo d.com/seminarseminar.html

[7] Mokhtar Ahmad, Tekanan kerja di kalangan guru sekolah menengah: Satu kajian di Daerah Kulim Bandar Baharu, Kedah Darul

[8] Aman, unpublished masters thesis. Bintulu: Universiti Malaysia Sarawak, 1995.

[9] J. Mukundan, \& K. Khandehroo, Burnout among English Language teachers in Malaysia. Contemporary Issues In Education Research, 3(1), 2010, 71-76.NUTP (2005). Available: http://www.nutp org

[10] J. Mukundan, \& K. Khandehroo, Burnout in relation to gender, educational attainment, and experience among Malaysian ELT

[11] practitioners. The Journal of Human Resource and Adult Learning, 5 (2), 2009, 93 - 98.

[12] Abdul Muin Sapidin. (2005). Stres guru membimbangkan - Akibat banyak perubahan dan bebanan tugas yang keterlaluan - NUTP,

[13] Berita Harian Malaysia [online]. Available: http://s4.invisionfree.com/wantar/ar/t105.htm

[14] H. J. Freudenberger, Staff burnout, Journal of Social Issues, 30, 1974, 159-164.

[15] C. Maslach, Burnout: Human Behavior, 5(9), 1976, 16-22.

[16] S. Carter. (1994). Organizing systems to support competent social behavior in children and Youth [online]. Available:http://interact.uoregon.edu/wrrc/Burnout.html

[17] H. Seyle, Stress in health and disease (MA: Butterworth, Reading, 1976). 
[18] B. A. Farber, Stress and burnout in suburban teachers, Journal of EducationalResearch, 77 (6), 1984a, 325-331.

[19] J. Dunham, Stress in teaching (London: Routeledge Press, 1992).

[20] C. Lale. (2001). Symptoms of teacher stress in UK education, schools, and colleges [online] Available: http://www.teacherstress.co.uk.

[21] D. B. Posen. (1995). Stress management for patient and physician. Canadian Journal of Continuing Medical Education [online].

[22] Available: http://www.mentalhealth.com/mag1/fr51.html

[23] R. Mayben. (2007) Teacher burnout action research [online]. Available: http://www.bama.ua.edu/ rmayben/edbio1.htm\#_Hlk26863998

[24] J. R. Cheek, L. J. Bradley, G. Parr \& W. Lan, Using music therapy techniques to treat teacher burnout. Journal of Mental Health Counseling, 25(3), 2003, 204-217.

[25] A. S. Antoniou, F. Polychroni, \& B. Walters. (2000). Sources of stress and professionalburnout of teachers of special education

[26] needs in Greece. Proceedings of the International Special Education Congress 2000 [Online]. Available: http://www.isec2000.org.uk/abstracts/papers_p/polychroni_1.htm

[27] M. G. Borg \& J. M. Falzon, Stress and job satisfaction among primary school teachers in Malta. Educational Review, 41, 1989, 271-279.

[28] S. A. Capel, Stress and burnout in teachers. European Journal of Teacher Education, 15, 1992, 197-211.

[29] C. Kyriacou, Stress, health, and schoolteachers: A comparison with other professions. Cambridge Journal of Education, 10, 1980, 154-158.

[30] I. A. Kytaev-Smyk, Psychology of stress (Moskow, USSR: Science, 1983).C. Lale. (2001). Symptoms of teacher stress in UK education, schools, and colleges. Available: http://www.teacherstress.co.uk.

[31] B. Rudow, Stress and burnout in the teaching profession: European studies, issues, and research perspectives, in Understanding and

[32] preventing teacher burnout: A sourcebook of international research and practice, R. Vandenberghe \& A. M. Huberman (Eds.).

[33] Cambridge, UK: Cambridge University Press, 1999, pp. 38-58).

[34] L. Lumsden, Teacher morale. Eugene, OR: ERIC Clearinghouse on EducationalManagement (ERIC Document Reproduction

[35] Service No. ED 422601, 1998).C. Kyriacou, Teacher stress and burnout: an international review. Educational Research, 29(2), 1987, 146-152.

[36] Algemeen burgerlijk pensioenfonds, Arbeidsongeschiktheid, ambtenaren: Een statistisch overzicht. Onderwijs [Incapacity in public

[37] service professions: A statistical overview.Educators]. Heerlen, The Netherlands: Author, 1995.

[38] J. Milne. (1999). Questionnaires: Advantages and disadvantages [online]. Available: http://www.icbl.hw.ac.uk/ltdi/cookbook/info_questionnaires/index.html

[39] C. Maslach, Burnout: The cost of caring. (Englewood Cliffs, NJ: Prentice Hall, 1982).

[40] M. Eker \& A. Anbar, Work Related Factors That Affect Burnout among Accounting and Finance Academicians, İş, Güç: The

[41] Journal of Industrial Relations and Human Resources, 2008.

[42] D. Byrne, Work, employment and society. (UK: BSA Publications Ltd.,1999).

[43] C. Maslach, W. B. Schjaufeli \& M. P. Leiter, Job Burnout. Annual Review of Psychology, 52(1), 2001, 397-422.

[44] J. Mukundan \& K.Khandehroo, Burnout among English Language teachers in Malaysia. Contemporary Issues In

[45] Education Research, 3(1), 2009, 71-76.

[46] (2009) Preventing burnout: signs, symptoms, causes and coping strategies. Helpguide.org.[online]. Available: http://www.helpguide.org/mental/burnout_signs_symptoms.htm 